\title{
Implementing the organic farming concept in strategies of sustainable development: European and Russian perspectives
}

\author{
0. Voronkova, 0. Vysotskaya
}

\author{
Altai State University \\ Lenin St. 61, 656049, Barnaul, Russian Federation \\ E-mail: olka2004@yandex.ru, vyssotskaya olga@mail.ru
}

Received: 14.08.2019. Accepted: 26.09.2019

\begin{abstract}
The tradition of organic agriculture is at present increasingly strengthening its position in European countries and becoming a paradigm for building up sustainable development strategies, ecological and economic security of regions. A more ecological model becomes a necessity today. It offers a great opportunity for European producers of organic products to get a long-term sustainability and competitive advantages/ The world economic crisis has further influenced and forced the interest of producers and consumers in high-quality and safe products. The article considers approaches to implementing the organic farming concept as part of building up strategies of sustainable development of EU regions in comparison with the Russian Federation, analyzes the main state mechanisms of this process.
\end{abstract}

Key words: Sustainable development; Organic agriculture; Paradigm; Strategies; Competitiveness

\section{Introduction}

An analysis of the works of foreign researchers over the past 5-10 years has revealed a tendency to consider organic agriculture in the paradigm of sustainable development of regions. The concept of sustainable development is based on the principles on which the implementation of the concept of organic agriculture is largely based. These principles are set forth in the Declaration and other documents of the UN Conference on Environment and Development (Rio de Janeiro, 1992), as well as in the materials of the XIX special session of the UN General Assembly (New York, 1997), and are determined by the concept's main goal - survival humanity, which means preserving the biosphere, biodiversity and ecosystems.

Organic farming is a form of agriculture that uses fertilizers and pesticides (including herbicides, insecticides and fungicides), that are considered natural, but it excludes or strictly restricts the use of various methods, including chemical fertilizers and pesticides; plant growth regulators, such as hormones; the use of antibiotics in livestock; genetically modified organisms; et al. (European Commission, 2014). Therefore, it relies on methods such as crop rotation, green manure, compost, and biological pest control (European Commission, 2014). According to some research papers (Gold, 2007), the US Department of Agriculture's National Organic Standards Board defines organic agriculture as an environmental production management system that promotes and enhances soil biodiversity, biological cycles, and biological activity. It is based on the minimal use of resources outside the farm and on management methods that restore, maintain and improve environmental harmony. The USDA Consumer Brochure defines organic products as those that are produced by farmers who focus on the use of renewable resources and the conservation of soil and water to improve the environment for future generations. The guarantor of the quality and safety of such products is the state represented by certification bodies approved at the government level.

In Europe the chemical industry is growing faster than the economy as a whole (Mercadi, V., 2016). Many agricultural practices can put pressure on the environment and cause soil degradation, water scarcity, environmental pollution and loss of natural habitat and biodiversity. Thus, numerous scientific publications and toxicological and epidemiological studies have shown that many pesticides become much more dangerous over time, which affects not only the ecosystem balance and biodiversity in general, but also covers the field of healthcare. Such effects are called externalities and are one of the classic causes of a failure in the institutional paradigm.

On the contrary, a well-developed agricultural system should be able to counteract climate change and help preserve the biological diversity of animals and plants and provide an integrated approach to maintaining public health.

The main idea of organic production is the high quality of natural products. Quality comes first, and quantity and yield are less significant. Lower yields of organic crops are offset by higher prices for organic products, which leads to the desire of consumers to pay more money for safer and more natural products. Goewie (2002) reveals the challenges that the organic sector is currently facing, as well as the opportunities and threats that organic production is expected to face in the coming years. According to the author, the success of organic production is based on producers who are well motivated by their role in society as a whole, as well as the actual needs of consumers. A significant number of researchers believe that not only the advantages of organic agriculture can be distinguished: conservation of soil and water resources, improving soil and water quality, increasing diversity, maintaining yields, producing quality products, natural pest control with less environmental pollution, but also numerous disadvantages : labour intensity, it requires constant attention and skills, needs a sufficient amount of natural resources, and in transition periods (two years for agricultural governmental cultures) often yield reduction occurs (Prasad, 2005, Eickhout et al., 2007)

It is considered that food security and organic farming lead to completely different types of land use: one is intensive and the other is extensive. Traditional agriculture is a model of intensive or productive agriculture (Morgan and Murdoch, 2000). The key concept in traditional agriculture is efficiency, which is due to high productivity is based on the intensive use of factors: machines, pesticides, 
fertilizers, seeds, etc. However, with the widespread use of chemicals, the connection between the farm and the local ecosystem was largely disrupted. In many ways, productivity is achieved through the use of chemicals in weed and pest control, as well as in fertilizing crops. But the use of chemicals harms the environment and ecological systems, as well as human health. According to researchers, organic agriculture appeared without any support of the government, scientific institutions, extension services or special legislation: "From the very beginning, organic producers were people acting on the basis of internal craving, passion, courage, perseverance and team spirit. Already at an early stage, they saw flaws in the use of synthetic chemicals and therefore supported traditional methods such as crop rotation and organic fertilizer - methods that they considered trustworthy " (Goewie, 2002).

\section{Methods}

As theoretical and methodological basis of the study materials from foreign scientists on the problems of agricultural production of organic products, as well as materials from relevant professional associations and EU statistics bodies were considered. Analysis was conducted on basis of the systematic approach that made it possible to ensure the complexity and focus of the study (Dore' et al., 2011). The study also used analytical, economic and statistical, monographic research methods (Dore' et al., 2011; Groot, Rossing, 2011).

\section{Results and Discussion}

New European Agriculture Development Strategy 2014-2020 allows for a change in established paradigms, including organic and sustainable agriculture. Aspects of sustainable rural development systematically cover many issues, ranging from the problems of rural tourism development (Andrei et al., 2014) to approaches related to food and environmental safety (Istudor et al., 2014). The European Union is committed to promoting sustainable agriculture as part of its Common Agricultural Policy (CAP). This is one of the objectives of Articles 2 and 3c of the Amsterdam Treaty. It is imperative that the European Union "promotes the harmonious, balanced and sustainable development of economic activity ... a high level of protection and improvement of the quality of the environment (Article 2)", and also that "environmental protection requirements should be included in the definition and implementation of public activities and policies, in particular with a view to promoting sustainable development (Article 3c)" (European Commission, 2014) The following priorities are highlighted in the EU CAP Sustainability Paradigm:

- $\quad$ EU food independence and food safety;

- Development of rural areas of the EU;

- $\quad$ EU participation in maintaining equilibrium in the global food market;

- $\quad$ EU response to climate change and environmental improvement.

- In a complex agricultural policy, organic production is seen as more sustainable, since it causes less damage to the environment, is able to adapt to climate change and maintain a stable level of soil fertility over a longer period of time. The basic principles of the organic development strategy established by IFOAM comply with the principles of sustainable development:

- The principle of ecology: Organic agriculture is based on the principles of the existence of natural ecological systems and cycles, coexisting with them and supporting them;

- The principle of health: Organic agriculture supports and improves the health of the soil, plant, animal, human and planet as a single system;

- The principle of care: Organic agriculture management is preventive and responsible in order to protect the health and well-being of present and future generations and the environment;

- The principle of justice: Organic agriculture is built on relationships that guarantee justice, taking into account the environment and human capabilities.

By comparison, in the Russian Federation in the main program documents (the Concept of Sustainable Development of Rural Areas, 2010; the Federal Law "On the Development of Agriculture", 2006), the concept of sustainable development does not correlate with the term "organic agriculture", but rather with issues of providing the necessary infrastructure and living standards of the population. And the concept of environmental development of the agro-industrial complex includes only the concept of non-waste production.

Three categories or levels of "organic" products are distinguished in the EU:

- "Organic products" - Consist of 95-100\% organic ingredients;

- The term "organic" is used only in the list of ingredients - If the product contains $70-94 \%$ of organic ingredients;

- The absence of the word "organic" on the package - If the product contains less than $70 \%$ of organic ingredients.

In the Russian Federation, the law "On Organic Products and Amending Certain Legislative Acts of the Russian Federation" enters into force only in January 2020 and contains an extremely generalized definition of organic products as environmentally friendly agricultural products, raw materials and food.

The main conditions and prerequisites for implementing the organic agriculture concept in the sustainable development strategies of the regions are presented in Table 1.

Table 1. Conditions for embedding organic agriculture in regional sustainable development strategies (comparison of the EU and the Russian Federation).

\begin{tabular}{lll}
\hline Conditions & EU & Russian Federation \\
\hline Legal Framework & Balanced (developed) & Unbalanced (developing) \\
$\begin{array}{l}\text { Definition of sustainable } \\
\text { development of rural } \\
\text { regions }\end{array}$ & $\begin{array}{l}\text { Correlates with organic agriculture, the } \\
\text { principles of the concept of sustainable agriculture, it assumes only the } \\
\text { development are the basis for the } \\
\text { development of organic agriculture }\end{array}$ & $\begin{array}{l}\text { Does anfrastructure security of the territory } \\
\text { and the material security of its } \\
\text { inhabitants }\end{array}$ \\
\hline
\end{tabular}




\begin{tabular}{|c|c|c|}
\hline $\begin{array}{l}\text { Definition of organic } \\
\text { products }\end{array}$ & $\begin{array}{l}\text { Ranked by category, extremely } \\
\text { concretized }\end{array}$ & Extremely generalized \\
\hline $\begin{array}{l}\text { State } \\
\text { measures }\end{array}$ & $\begin{array}{l}\text { Price regulation, subsidizing the transition } \\
\text { to organic agriculture, lending, subsidies } \\
\text { for biological assets of livestock and crop } \\
\text { production government orders, improving } \\
\text { the quality of agricultural products and } \\
\text { protecting the environment }\end{array}$ & $\begin{array}{l}\text { Credit granting, subsidizing (chemical } \\
\text { plant protection products), carrying out } \\
\text { purchasing and commodity interventions } \\
\text { in food markets, as well as carrying out } \\
\text { collateral operations, preferential } \\
\text { taxation, customs and tariff regulation } \\
\text { taking into account domestic and } \\
\text { international markets }\end{array}$ \\
\hline Share of state financing & $\begin{array}{l}45-50 \% \text { of the value of agricultural } \\
\text { products }\end{array}$ & $\begin{array}{l}3-5 \% \text { of the value of agricultural } \\
\text { products }\end{array}$ \\
\hline
\end{tabular}

In the EU, instruments have been formed to implement the strategy of organic agriculture based on the principles of sustainable development, and these instruments can be ranked into two groups: ensuring supply stability and demand stability. The general strategy of organic farming in the EU in the paradigm of sustainable development is embodied at the level of separate EU states. At the end of the last century, many countries of the European Union developed national programs for the development of organic agriculture, which were primarily aimed at increasing the area and number of enterprises producing organic products. Within the framework of these programs, it is planned to pay annual subsidies to enterprises producing organic products, conduct information campaigns for the population in the media about the benefits of natural nutrition and a healthy lifestyle, provide assistance to national associations of organic producers, and finance research. So, from the general budget of the European Union aimed at ensuring food security (3.8 billion euros), in 2015 - 2016461 million euros were accounted for research in the field of organic production. Organic producers, in accordance with the new EU legislation, must use the official logo of the European Union. At the same time, food safety standards are the same for all types of food products, and certification applies only to the production of organic goods.

Compared with the EU, in the Russian Federation there currently does not exist a system of strategic planning for organic agriculture similar to the EU countries in the sustainable development paradigm, respectively, the tools used in the EU are absent. However, the opposite situation is observed when particelar regions take the initiative to develop a strategy for the transition to organic agriculture.

For example, in the Belgorod region, a long-term target program has been adopted to introduce a biological farming system, which provides for financing activities aimed at reviving arable land, improving the seed stock, and popularizing biological fertilizers. In general, in the Russian Federation, organic agriculture is currently the initiative of individual farms focused on selling their products in Europe, which in fact leads to the export orientation of organic agriculture, which is fundamentally different from the postulates of the sustainable development policy of the EU countries, focused on ensuring food and environmental security of the domestic market.

\section{Conclusion}

Based on the conducted research, it should be noted that there are serious differences between the model of sustainable development of organic agriculture in the EU and the Russian Federation that must be overcome. This applies primarily to the harmonization of the regulatory framework and tools for the development of organic agriculture.

Organic agriculture in the Russian Federation should be considered in close connection with social responsibility and environmental sustainability as a technological alternative to traditional agriculture in terms of ensuring food safety for the population, as well as the core of the concept of sustainable rural development. To do this, it is necessary to take a number of steps, first of all, at the state and regional levels:

- To harmonize legislation in the field of sustainable development with the inclusion of aspects of organic agriculture,

- In accordance with this legislation, to develop targeted programs for the sustainable development of rural areas with the inclusion of an organic agriculture component in them,

- To form tools for the implementation of these programs, based on the experience of the EU countries,

- If possible, to reorient the scope of organic agriculture to meet the needs and requirements of the domestic market in order to ensure food security of the country.

\section{Acknowledgement}

This research was supported by RFBR, Project 17-02-00639-OGN

\section{References}

Andrei, D., Gogonea, R. (2014) Is Romanian rural tourism sustainable? Revealing particularities

Sustainability, 6 (12), 8876-8888

Dore', T., Makowski, D., Male'zieux, E., Munier-Jolain, N., Tchamitchian, M., Tittonell, P. (2011). Facing up to the paradigm of ecological intensification in agronomy: revisiting methods, concepts and knowledge. Eur J Agron, 34, $197-210$.

Eickhout, B., Meijl, H., Tabeau, A., Rheenen, T. (2007). Economic and ecological consequences of four European land use scenarios. Land Use Policy, 24 (3), 562-575,

European Commission, Agriculture and Rural Development Department. What is Organic Farming?

(2014) Retrieved from: http://ec.europa.eu/agriculture/organic/organic-farming/what-is-organic-farming/index_en.htm

Gold, M. V., (2007). Organic Production and Organic Food: Information Access Tools Alternative Farming Systems Information Center. USDA National Agricultural Library. Retrieved from http://www.nal.usda.gov/afsic/pubs/ofp/ofp.shtml

Groot, J.C.J., Rossing, W.A.H. (2011). Model-aided learning for adaptive management of natural resources: an evolutionary design perspective. Methods Ecol Evol, 2, 643-650.

Istudor, N., Ion, I., Sponte, M., Petrescu, I. (2014). Food security in Romania-a modern approach for developing sustainable agriculture. Sustainability, 6 (12), 8796-8807,

Mercadi, V. (2016). Organic agriculture as a paradigm of sustainability: Italian food and its progression in the global market. Agriculture and Agricultural Science Procedia, 8, $798-802$. 
Morgan, K., Murdoch, J. (2000). Organic vs. conventional agriculture: knowledge, power and innovation in the food chain. Geoforum, 31 (2), 159-173

Prasad, R. (2005). Organic farming vis-à-vis modern agriculture. Curr. Sci., 89 (2), 252-254

\section{Citation:}

Voronkova, O., Vysotskaya, O. (2019). Implementing the organic farming concept in strategies of sustainable development: European and Russian perspectives. Ukrainian Journal of Ecology, 9(3), 421-424.

(cc) $\mathrm{Er}$ This work is licensed under a Creative Commons Attribution 4.0. License 